\title{
Experimental Investigation on Relationship \\ between Sedimentation Rate Constants of Solid Materials
}

\author{
K.Senthilkumar (Corresponding author) \\ Department of Chemical Engineering \\ Erode Sengunthar Engineering College, Thudupathi \\ Erode-638057, Tamilnadu, India \\ Tel: 91-4294-232-701_E-mail: uksen2003@yahoo.co.in \\ V. Sivakumar \\ Department of Chemical Engineering \\ Kongu Engineering College, Perundurai \\ Erode-638052, Tamilnadu, India \\ Tel: 91-4294-225-026 E-mail: drvsivakumar@yahoo.com \\ T. Kannadasan \\ Director of Research \\ Anna University- Coimbatore, GCT Campus \\ Coimbatore-641013, Tamilnadu, India
}

Tel: 91-422-245-4571Ｅ-mail: tkannadasan56@yahoo.com

\begin{abstract}
It has been fount that the sedimentation process is a rate-governed process, which is a combination of a constant rate and falling rate. The various solid materials like Silicate, Calcium Carbonate, and Barium Carbonate were taken and ground in prototype ball mill and sieved to different size fractions and different consistence sedimentation tests were conducted. In this study, an attempt has been made to draw some correlations between sedimentation rate constants (overall sedimentation rate constant $\left(\mathrm{K}_{\mathrm{o}}\right)$, sedimentation rate constant for constant rate period $\left(\mathrm{K}_{\mathrm{c}}\right)$ and falling rate constant $\left(\mathrm{K}_{\mathrm{f}}\right)$ ). Variation of $\mathrm{K}_{\mathrm{o}}$ on various particle sizes and slurry consistency has also been reported in this work.
\end{abstract}

Keywords: Sedimentation rate, Sedimentation rate constant, Falling rate, Sedimentation rate correlation

\section{Introduction}

The separation of dilute slurry by gravity setting into a clear fluid and slurry of higher solids concentration is called sedimentation. Sedimentation is applied in many chemical engineering operations and processes such as filtration, fluidization, two- phase flow and environmental engineering (McCabe et al., 1993). The rate data of sedimentation process is very important for designing equipment used in chemical and metallurgical practices for separating suspended solid particles from liquid or gas stream (Mondal and Majumdar, 2004). Industrial sedimentation operations may be carried out batch- wise or continuously using thickeners. The hydrodynamic analysis of the sedimentation process facilitates the design of thickener (Coulson et al, 1962). Viscosity of the medium is the main physical property, which affects the sedimentation. Density of particles is again an important factor that affects the settling velocity of the particles. When the density of the particles is more, then the settling rate is also more. Batch sedimentation is employed for bio-processing or the process fluids in recycle. Batch sedimentation is mainly used in pharmaceutical industries. Continuous sedimentation is the process in which the solids are settled continuously. This type of sedimentation is found in chemical industries, which reuse the process water or fluid. They are carried out in large diameters and shallow depth diameters, with slowly revolving rakes for removing the sludge. In the binary system, two different sizes of particles are taken and are used for the study of sedimentation process. The mechanism of binary system of sedimentation can be well understood (Brown, 1962). In general, a binary mixture consisting of particles of equal densities will give rise to four zones during the course of sedimentation. 
From the literature (Brown, 1962), it is observed that the sedimentation rate is proportional to the difference between the interfacial height at any time $(\mathrm{H})$ and that attained at equilibrium $\left(\mathrm{H}_{\mathrm{E}}\right)$ [when no further change in the height of sedimented layer occurs]: $(-\mathrm{dH}) / \mathrm{dt} \alpha\left(\mathrm{H}-\mathrm{H}_{\mathrm{E}}\right)$. In general, the entire sedimentation period is found to be a combination of a constant rate period, which is followed by a falling rate period. The sedimentation rate falls till it vanishes at equilibrium height $\left(\mathrm{H}_{\mathrm{E}}\right)$. Depending upon the type of period, the proportionality constant is known as constant rate $\left(\mathrm{K}_{\mathrm{c}}\right)$ or falling rate period constant $\left(\mathrm{K}_{\mathrm{f}}\right)$ respectively, which are operative between the intervals, $\mathrm{H}_{\mathrm{c}} \leq \mathrm{H}<\mathrm{H}_{\mathrm{o}}$ for $0<\mathrm{t} \leq \mathrm{t}_{\mathrm{c}}$ and $\mathrm{H}_{\mathrm{E}} \leq \mathrm{H}<\mathrm{H}_{\mathrm{c}}$ for $\mathrm{t}_{\mathrm{c}}<\mathrm{t} \leq \mathrm{t}_{\mathrm{E}}$. If this condition is applied on overall basis between the initial interfacial height $\left(\mathrm{H}_{\mathrm{o}}\right)$ and the equilibrium height $\mathrm{H}_{\mathrm{E}}$, the rate constant is called overall sedimentation rate constant $\left(\mathrm{K}_{\mathrm{o}}\right)$. In this study, an attempt has been made to draw the correlations between these sedimentation rate constants $\mathrm{K}_{\mathrm{c}}, \mathrm{K}_{\mathrm{f}}$ and $\mathrm{K}_{\mathrm{o}}$. Variation of overall sedimentation rate constant $\left(\mathrm{K}_{\mathrm{o}}\right)$ on various particle size and slurry consistency has also been described in this work.

\section{Materials and Methods}

The solids of various materials like Calcium Carbonate $\left(\mathrm{CaCO}_{3}{ }^{2}\right.$, Barium Carbonate $\left(\mathrm{BaCO}_{3}\right)$ and Silicate were taken and ground in proto type ball mill and sieved to four different size fractions of 52/60,60/72, 72/100 and 100/200 mesh BSS corresponding to particle size of $0.246 \mathrm{~mm}, 0.212 \mathrm{~mm}, 0.147 \mathrm{~mm}$ and $0.072 \mathrm{~mm}$ respectively. To make them dust free, the individual size fractions were washed in a gentle stream of water. The required quantities of the solids were put inside a $500 \mathrm{ml}$-measuring cylinder to make the slurry of a particular consistency. A strip of graph paper was attached to a measuring cylinder to ensure more precise reading. The slurry was stirred and allowed to settle. The height of interface was read from bottom and kept on being continuously recorded with time t, measured by a stopwatch to denote the rate of sedimentation at any time instant. The true density was measured by specific gravity bottle (Perry $\&$ Green, 1997).

\section{Results and Discussion}

In the experimental data, for each of the runs, the initial height of the slurry $\left(\mathrm{H}_{\mathrm{o}}\right)(\mathrm{at} \mathrm{t}=0)$, was obtained directly and the equilibrium height $\left(\mathrm{H}_{\mathrm{E}}\right)$ was determined graphically from the rectangular plot of $\mathrm{H}$ against $\mathrm{t}$. It is clear from these plots that the curves tend to be more and more flat with the increase of the solids concentration, which results in a progressive decrease in the value of sedimentation rate. The critical height $\left(\mathrm{H}_{\mathrm{c}}\right)$ was obtained from a differential plot of the variation of $-\Delta \mathrm{H} / \Delta \mathrm{t}$ against time $\mathrm{t}$, as the break point between the constant and falling rates.

Though it has been mentioned that the rate of sedimentation is proportional to $\left(\mathrm{H}-\mathrm{H}_{\mathrm{E}}\right)$ and raised to the power 1.0 (Brown, 1962, Perry \& Green, 1997), it has been found in the present study that this assumption fails to give good result which is obtained by putting the exponent of $\left(\mathrm{H}-\mathrm{H}_{\mathrm{E}}\right)$ as 0.1 instead of 1.0 . The modified exponential term gives a good result in the standard deviation between the calculated and experimental values of $\mathrm{H}$. So, the proportionality is modified as,

$$
-\mathrm{dH} / \mathrm{dt} \alpha\left(\mathrm{H}-\mathrm{H}_{\mathrm{E}}\right)^{0.1}
$$

The proportionality constant is known as Sedimentation rate constant K. This equation (1) is integrated between the desired limits to obtain the values of different $\mathrm{K}$.

For constant rate period,

$$
-\mathrm{dH} / \mathrm{dt}=\text { constant }
$$

Integrating this equation between the limits $\mathrm{H}_{\mathrm{c}} \leq \mathrm{H}<\mathrm{H}_{\mathrm{o}}$ for $0<\mathrm{t} \leq \mathrm{t}_{\mathrm{c}}$

$$
\left(\mathrm{H}_{\mathrm{o}}-\mathrm{H}_{\mathrm{c}}\right) / \mathrm{t}_{\mathrm{c}}=\mathrm{K}_{\mathrm{c}}
$$

Where, $\mathrm{t}_{\mathrm{c}}$ is the critical time (the value of time $\mathrm{t}$ corresponding to the break point between constant and falling rates) and the corresponding height is the critical height $(\mathrm{Hc})$.

For falling rate period,

$$
-\mathrm{dH} /\left(\mathrm{H}-\mathrm{H}_{\mathrm{E}}\right)^{0.1} \quad \alpha \mathrm{dt}
$$

Integrating this equation between the limits $\mathrm{H}_{\mathrm{E}} \leq \mathrm{H}<\mathrm{H}_{\mathrm{c}}$ for $\mathrm{tc}<\mathrm{t} \leq \mathrm{t}_{\mathrm{E}}$

$$
1.1\left[\left(\mathrm{H}_{\mathrm{c}}-\mathrm{H}_{\mathrm{E}}\right)^{0.9}-\left(\mathrm{H}-\mathrm{H}_{\mathrm{E}}\right)^{0.9}\right]=\mathrm{K}_{\mathrm{f}} \mathrm{t}
$$

For overall conditions,

$$
-\mathrm{dH} /\left(\mathrm{H}-\mathrm{H}_{\mathrm{E}}\right)^{0.1}=\mathrm{K}_{\mathrm{o}} \mathrm{dt}
$$

Integrating this equation for entire period of the initial interfacial height $(\mathrm{Ho})$ and the equilibrium height $\mathrm{H}_{\mathrm{E}}$,

$$
1.1\left[\left(\mathrm{H}_{\mathrm{o}}-\mathrm{H}_{\mathrm{E}}\right)^{0.9}-\left(\mathrm{H}-\mathrm{H}_{\mathrm{E}}\right)^{0.9}\right]=\mathrm{K}_{\mathrm{o}} \mathrm{t}
$$

The values of $\mathrm{K}_{\mathrm{f}}$ and $\mathrm{K}_{\mathrm{o}}$ can be easily calculated from the rectangular plots of the left hand side of equation (5) and equation (7) against $t$ or $t-t_{c}$, respectively as the corresponding slopes. The unbiased values have been determined by 
using least square technique. The values of $\mathrm{K}_{\mathrm{c}}$ can be calculated directly by using the equation (3) for each of the experiments performed. The calculated values of $\mathrm{K}_{\mathrm{o}}, \mathrm{K}_{\mathrm{c}}$ and $\mathrm{K}_{\mathrm{f}}$ are tabulated in the Table 1 and Table 2.

In the process of finding the type of relationship between the rate constants $\mathrm{K}_{\mathrm{c}}, \mathrm{K}_{\mathrm{f}}$ and $\mathrm{K}_{\mathrm{o}}$, it has been found that the variation of overall sedimentation rate constant $(\mathrm{Ko})$ with the summation of the constant and falling rates $\left(\mathrm{K}_{\mathrm{c}}+\mathrm{K}_{\mathrm{f}}\right)$ as shown in Table 3 and Table 4 and also plotted on a rectangular graph paper which forms a straight line. This relation can be expressed by (in general)

$\left|\mathrm{K}_{\mathrm{o}}\right|=\mathrm{m}\left|\left(\mathrm{K}_{\mathrm{c}}+\mathrm{K}_{\mathrm{f}}\right)\right|+\mathrm{C}_{1}$

The values of $\mathrm{m}$ and $\mathrm{C}_{1}$ have been calculated by using least square technique for all the runs and which is given in Table5.

The overall sedimentation rate constant is also found to be dependent on slurry concentration for a constant particle size. Such dependence can be expressed with a fair degree of accuracy by the relation,

$\mathrm{K}_{\mathrm{o}}=\mathrm{A}_{1}(\mathrm{C})^{\mathrm{B}}{ }_{1}$

The plot plotted between $\ln \left(\mathrm{K}_{\mathrm{o}}\right)$ versus $\ln (\mathrm{C})$ satisfies the relation expressed in equation (9). From the results (Table 6 ) it is observed that the value of $B_{1}$ has decreased with increase in particle size in slurry and the value of $A_{1}$ has also decreased with increase of particle size of the slurry of the same consistency.

\section{Conclusion}

The batch sedimentation tests were conducted for the various materials like Silicate, Calcium Carbonate, and Barium Carbonate with various particle sizes and concentrations. Correlation has been made to relate the sedimentation rate constants like $\mathrm{K}_{\mathrm{c}}, \mathrm{K}_{\mathrm{f}}$, and $\mathrm{K}_{\mathrm{o}}$. Variation of $\mathrm{K}_{\mathrm{o}}$ on various particle sizes and slurry consistency has also been reported in this work. In addition, over all sedimentation rate constant and slurry concentration were related by the equation $\mathrm{Ko}_{\mathrm{O}}=$ $\mathrm{A}_{1}(\mathrm{C}){ }_{1}^{\mathrm{B}}$. The values of $\mathrm{A}_{1}$ and $\mathrm{B}_{1}$ were related with particle size of the solid particles in the slurry.

\section{References}

Warren L. McCabe, Julian C. Smith \& Peter Harriett (1993). Unit operation of chemical engineering, McGraw Hill publications.

Mondal, P., Majumdar C.B (2004). Sedimentation of Hematite Water Slurries, Journal of the Institution of Engineers (I), $85,20-23$

Coulson J. M., Richardson J. F., Buckhurst J., Harker J. H. (1962). Coulson \& Richardson Chemical Engineering (volume 2), Asian Book Pvt. Ltd., 131

Brown G. G. (1962). Unit Operation, Asia publishing house, Calcutta, 117

Robert H.Perry \& Don Green (1997). Perry chemical engineer's hand book ( $7^{\text {th }}$ edition), McGraw Hill publications 


\section{Nomenclature}

$\begin{array}{ll}\mathrm{A}_{1} & : \text { Coefficient } \\ \mathrm{B}_{1} & : \text { Coefficient } \\ \mathrm{BSS} & : \text { British standard sieves } \\ \mathrm{C} & : \text { Percentage slurry consistency, }\left(\mathrm{Kg} / \mathrm{m}^{3}\right) \\ \mathrm{C}_{1} & : \text { Coefficient } \\ \mathrm{H} & : \text { Height of interface, } \mathrm{m} \\ \mathrm{H}_{\mathrm{E}} & : \text { Interfacial height at equilibrium, } \mathrm{m} \\ \mathrm{H}_{\mathrm{o}} & : \text { Initial height of the suspension }(\mathrm{at} \mathrm{t}=0), \mathrm{m} \\ \mathrm{K}_{\mathrm{o}} & : \text { Overall sedimentation rate constant, }(\mathrm{m})^{0.9}(\mathrm{sec})^{-1} \\ \mathrm{~K}_{\mathrm{f}} & : \text { Rate constant for falling rate period, }(\mathrm{m})^{0.9}(\mathrm{sec})^{-1} \\ \mathrm{~K}_{\mathrm{c}} & : \text { Rate constant for constant rate period, }(\mathrm{m})(\mathrm{sec})^{-1} \\ |\mathrm{~K}| & : \text { Modulus of } \mathrm{K} \\ \mathrm{C}_{1} & : \text { Coefficient } \\ -\mathrm{r}_{\mathrm{c}} & : \text { Rate of sedimentation, cm } / \mathrm{s} \\ \mathrm{D}_{\mathrm{p}} & : \text { Diameter of particle, cm } \\ \mathrm{t} & : \text { Time, sec } \\ \mathrm{t}_{\mathrm{c}} & : \text { Critical time, } \mathrm{s} \\ \mathrm{t}_{\mathrm{E}} & : \text { Equilibrium time, } \mathrm{s}\end{array}$


Table 1. Experimental values of $\mathrm{K}_{\mathrm{o}}, \mathrm{K}_{\mathrm{c}}$ and $\mathrm{K}_{\mathrm{f}}$ for $\mathrm{CaCO}_{3}$ and $\mathrm{BaCO}_{3}$

\begin{tabular}{|c|l|l|c|c|c|c|c|c|c|}
\hline Materials & \multicolumn{2}{|c|}{ Constant rate constant, $\mathrm{K}_{\mathrm{c}}$} & \multicolumn{2}{c|}{ Falling rate constant, $\mathrm{K}_{\mathrm{f}}$} & \multicolumn{3}{c|}{ Over all rate constant, $\mathrm{K}_{\mathrm{o}}$} \\
\hline & \multicolumn{1}{|c|}{$5 \%$} & $10 \%$ & $15 \%$ & $5 \%$ & $10 \%$ & $15 \%$ & $5 \%$ & $10 \%$ & $15 \%$ \\
\hline $\mathrm{CaCO}_{3}$ & 0.0853 & 0.0650 & 0.0317 & -0.10794 & -0.0356 & -0.0535 & 0.0624 & 0.0491 & 0.0294 \\
\hline $\mathrm{BaCO}_{3}$ & 0.148 & 0.1378 & 0.1308 & -0.23323 & -0.1827 & -0.1188 & 0.1118 & 0.0977 & 0.0751 \\
\hline
\end{tabular}

Table 2. Experimental values of $\mathrm{K}_{\mathrm{o}}, \mathrm{K}_{\mathrm{c}}$ and $\mathrm{K}_{\mathrm{f}}$ for Silicate

\begin{tabular}{|c|l|l|l|l|l|}
\hline Materials & \multicolumn{5}{|c|}{ Constant sedimentation rate period constant, $\mathrm{K}_{\mathrm{c}}$} \\
\hline Silicate (BSS) & \multicolumn{1}{|c|}{$5 \%$} & \multicolumn{1}{|c|}{$10 \%$} & $15 \%$ & \multicolumn{1}{c|}{$20 \%$} & \multicolumn{1}{c|}{$25 \%$} \\
\hline $52 / 60$ & 0.1203 & 0.1111 & 0.1025 & 0.1006 & 0.0915 \\
\hline $60 / 72$ & 0.1181 & 0.0974 & 0.0946 & 0.0931 & 0.0898 \\
\hline $72 / 100$ & 0.1086 & 0.0914 & 0.08333 & 0.0837 & 0.0754 \\
\hline $100 / 200$ & 0.0892 & 0.0872 & 0.0833 & 0.06926 & 0.0608 \\
\hline & \multicolumn{5}{|c|}{ Falling sedimentation rate period constant, $\mathrm{K}_{\mathrm{f}}$} \\
\hline Silicate (BSS) & $5 \%$ & $10 \%$ & $15 \%$ & $20 \%$ & $25 \%$ \\
\hline $52 / 60$ & -0.253 & -0.18528 & -0.18882 & -0.16147 & -0.13203 \\
\hline $60 / 72$ & -0.20459 & -0.16349 & -0.1514 & -0.12318 & -0.12299 \\
\hline $72 / 100$ & -0.19042 & -0.16628 & -0.13685 & -0.10249 & -0.12653 \\
\hline $100 / 200$ & -0.13137 & -0.14448 & -0.1086 & -0.13229 & -0.1155 \\
\hline & Overall sedimentation rate constant, Ko & & \\
\hline Silicate (BSS) & $5 \%$ & \multicolumn{1}{|c|}{$10 \%$} & $15 \%$ & $20 \%$ & $25 \%$ \\
\hline $52 / 60$ & 0.110702 & 0.094218 & 0.089433 & 0.086678 & 0.078563 \\
\hline $60 / 72$ & 0.104175 & 0.08577 & 0.078971 & 0.073904 & 0.071563 \\
\hline $72 / 100$ & 0.096321 & 0.080232 & 0.070811 & 0.064602 & 0.062312 \\
\hline $100 / 200$ & 0.064096 & 0.073587 & 0.064914 & 0.063097 & 0.055385 \\
\hline
\end{tabular}

Table 3. The values of $\left(\mathrm{K}_{\mathrm{c}}+\mathrm{K}_{\mathrm{f}}\right)$ and $\mathrm{K}_{\mathrm{o}}$ for $\mathrm{CaCO}_{3}$ and $\mathrm{BaCO}_{3}$

\begin{tabular}{|c|c|c|c|c|c|c|}
\hline \multirow[t]{2}{*}{ Materials } & \multicolumn{2}{|c|}{ For $\quad 5 \%$} & \multicolumn{2}{|c|}{ For $\quad 10 \%$} & \multicolumn{2}{|c|}{ For $\quad 15 \%$} \\
\hline & $\mathrm{K}_{\mathrm{c}}+\mathrm{K}_{\mathrm{f}}$ & $\mathrm{K}_{\mathrm{o}}$ & $\mathrm{K}_{\mathrm{c}}+\mathrm{K}_{\mathrm{f}}$ & $\mathrm{K}_{\mathrm{o}}$ & $\mathrm{K}_{\mathrm{c}}+\mathrm{K}_{\mathrm{f}}$ & $\mathrm{K}_{\mathrm{o}}$ \\
\hline $\mathrm{CaCO}_{3}$ & -0.02257 & 0.062473 & 0.029412 & 0.049105 & -0.02178 & 0.029244 \\
\hline $\mathrm{BaCO}_{3}$ & -0.08523 & 0.11187 & -0.04493 & 0.097779 & 0.011909 & 0.075109 \\
\hline
\end{tabular}


Table 4. The values of $\left(\mathrm{K}_{\mathrm{c}}+\mathrm{K}_{\mathrm{f}}\right)$ and $\mathrm{K}_{\mathrm{o}}$ for Silicate

\begin{tabular}{|c|c|c|c|c|c|c|c|c|c|c|}
\hline \multirow{2}{*}{$\begin{array}{c}\text { Silicate } \\
\text { (BSS) }\end{array}$} & \multicolumn{2}{|c|}{$5 \%$} & \multicolumn{2}{|c|}{$10 \%$} & \multicolumn{2}{|c|}{$15 \%$} & \multicolumn{2}{|c|}{$20 \%$} & \multicolumn{2}{|c|}{$25 \%$} \\
\hline & $\mathrm{K}_{\mathrm{c}}+\mathrm{K}_{\mathrm{f}}$ & $\mathrm{K}_{\mathrm{o}}$ & $\mathrm{K}_{\mathrm{c}}+\mathrm{K}_{\mathrm{f}}$ & $\mathrm{K}_{\mathrm{o}}$ & $\mathrm{K}_{\mathrm{c}}+\mathrm{K}_{\mathrm{f}}$ & $\mathrm{K}_{\mathrm{o}}$ & $\mathrm{K}_{\mathrm{c}}+\mathrm{K}_{\mathrm{f}}$ & $\mathrm{K}_{\mathrm{o}}$ & $\mathrm{K}_{\mathrm{c}}+\mathrm{K}_{\mathrm{f}}$ & $\mathrm{K}_{\mathrm{o}}$ \\
\hline $52 / 60$ & -0.1327 & 0.2348 & -0.0742 & 0.1247 & -0.0863 & 0.0840 & -0.0607 & 0.0707 & -0.0405 & 0.0658 \\
\hline $60 / 72$ & -0.08649 & 0.1519 & -0.0661 & 0.1153 & -0.0568 & 0.0793 & -0.030 & 0.06744 & -0.0332 & 0.0634 \\
\hline $72 / 100$ & -0.08182 & 0.1393 & -0.0748 & 0.1058 & -0.0535 & 0.0738 & -0.0189 & 0.0634 & -0.0511 & 0.061 \\
\hline $100 / 200$ & -0.04217 & 0.1307 & -0.0572 & 0.0999 & -0.0253 & 0.0673 & -0.063 & 0.06085 & -0.0547 & 0.0593 \\
\hline
\end{tabular}

Table 5. Value of constant for the relation among $\mathrm{K}_{\mathrm{o}}, \mathrm{K}_{\mathrm{c}}$ and $\mathrm{K}_{\mathrm{f}}$

\begin{tabular}{|c|l|l|}
\hline \multirow{2}{*}{ Materials } & \multicolumn{2}{|c|}{ Constants } \\
\cline { 2 - 3 } & $\mathrm{m}$ & $\mathrm{C} 1$ \\
\hline $\mathrm{CaCO}_{3}$ & 19.4213 & -0.442 \\
\hline $\mathrm{BaCO}_{3}$ & 0.51445 & 0.0706 \\
\hline For Silicate & \multicolumn{2}{|}{} \\
\hline $52 / 60 \mathrm{BSS}$ & 2.2346 & -0.0603 \\
\hline $60 / 72 \mathrm{BSS}$ & 1.6798 & -0.0039 \\
\hline $72 / 100 \mathrm{BSS}$ & 1.6362 & -0.0029 \\
\hline $100 / 200 \mathrm{BSS}$ & -14.867 & 0.8046 \\
\hline
\end{tabular}

Table 6. Value of constants for the relation between $\mathrm{K}_{\mathrm{o}}$ and $\mathrm{C}$

\begin{tabular}{|c|c|c|}
\hline \multirow{2}{*}{ Materials } & \multicolumn{2}{|c|}{ Constants } \\
\cline { 2 - 3 } & $\mathrm{A}_{1}$ & $\mathrm{~B}_{1}$ \\
\hline $\mathrm{CaCO}_{3}$ & 0.0093 & -0.6539 \\
\hline $\mathrm{BaCO}_{3}$ & 0.04099 & -0.3445 \\
\hline Silicate & $\mathrm{A}_{1}$ & $\mathrm{~B}_{1}$ \\
\hline $52 / 60 \mathrm{BSS}$ & 0.06139 & -0.1955 \\
\hline $60 / 72 \mathrm{BSS}$ & 0.05085 & -0.2350 \\
\hline $72 / 100 \mathrm{BSS}$ & 0.04186 & -0.2787 \\
\hline $100 / 200 \mathrm{BSS}$ & 0.0382 & -0.346 \\
\hline
\end{tabular}

